ПСИХОЛОГІЧНЕ БЛАГОПОЛУЧЧЯ СОЦІАЛЬНИХ ПРАЦІВНИКІВ

\title{
PSYCHOLOGICAL WELL-BEING OF SOCIAL WORKERS
}

УДК 159.922

DOI https://doi.org/10.32843/26635208.2020.16.15

\section{Петрасюк л.о.}

аспірант кафедри диференціальної і спеціальної психології

Одеський національний університет імені І.І. Мечникова
У статті розглядається проблема психологічного благополуччя та психологічного здоров'я соціальних працівників. Аналізуються фрактори і джерела психологічного благополуччя. Викладаються теоретичні основи дослідження - роботи вчених, які досліджували проблеми психологічного благополуччя соціальних працівників, найпоширеніші стресогенні чинники та їх вплив на працездатність робітника. Розглядаються найпоширеніші причини звільнення з робочого місця та фрактори, які найчастіше призводять до звільнення. Аналізується вплив емоційного стану працівника на ефективність та якість послуг, що надаються, на якість вирішення проблем клієнтів. Розглядається взаємозв'язок низького рівня психологічного благополуччя під час роботи соціального працівника та довіри клієнта до агенції загалом. У той же час аналізується сприйняття соціальним працівником клієнта у стані перенавантаження та стресу. Особлива увага приділяється твердженню, що на чей час домінуючу роль у самоідентичності людини грає саме професія, тому профресійні чинники мають істотний вплив на рівень суб'єктивного благополуччя працівника. Наголошено, що високий рівень суб'єктивного благополуччя підтримує продуктивність, задоволеність життям, соціально бажану поведінку $i$ хороший фрізичний $i$ психічний стан здоров'я, може сприяти продуктивності праці, зменшенню рівня прогулів і рівня плинності кадрів. Водночас $з$ негативними фракторами впливу розглядаються фрактори позитивного впливу та мотивації в просресії та шляхи самостійного подолання стресу, які вживаються серед опитаних працівників, у яких досить високий рівень психологічного благополуччя. Особлива увага приділяється необхідності психологічної підтримки працівників, яка має надаватися в тому числі керівництвом, а також можливості терапії в професійних групах з урахуванням особистісних потреб. Також у чентрі уваги постають зовнішні та внутрішні проблеми організацій, такі як плинність кадрів, що спричинює перенавантаження працівників та робить неможливим повноцінну, своєчасну відпустку для відновлення сил, що збільшує рівень прогулів та знижує ефективність послуг.
Ключові слова: психологічне благополуччя, соціальні працівники, психологічна підтримка, стресогенні фрактори, плинність кадрів, перенавантаження.

The article deals with the problems of psychological well-being and psychological health of social workers. The factors and sources of psychological well-being are analyzed. The theoretical foundations of the study are presented by the work of scientists who have studied the problems of psychological well-being of social workers; also it exposes the most common stressors and their impact on the efficiency of the worker. The most common reasons for dismissal and the factors that most often lead to dismissal are considered. The article analyzes the influence of the emotional state of the employee on the efficiency and quality of services that are provided along with the quality of solving customer problems. The following article considers the correlation between the low level of psychological well-being and the employee's ability to work, which can result in clients disbelief in agency and it services. At the same time, the social worker's perception of the client in a state of being overload and stress is analyzed.

Particular attention is paid to the statement that currently the dominant role in human self-identity is played by the profession, so professional factors have a significant impact on the level of subjective well-being of the employee.

Along with the negative factors of influence, the following article also provides information about the factors of positive influence and motivation in the profession and mentions the ways how to help yourself cope with stress, to manage anger and your anxiety which are used among the surveyed workers, who have a fairly high level of psychological well-being.

Particular attention is paid to the need for psychological support of employees, which should be provided, including management, as well as the different types of therapy to relieve stress in professional groups, taking into account personal needs. The article is also focused on the external and internal problems of organizations, such as staff turnover, which overloads employees and makes it impossible to take full, timely rest, which increases absenteeism and reduces the efficiency of services.

Key words: psychological well-being, social workers, psychological support, stressors, staff turnover, overload.
Постановка проблеми. Психологічне благополуччя особистості - одна з найбільш актуальних проблем сучасної психології. Складність вивчення феномену психологічного благополуччя зумовлена тим, що механізм його формування знаходиться як у соціальному середовищі, так і у внутрішньому світі людини. Проблема психологічного благополуччя розглядається в різних аспектах, вче- ними визначаються його джерела та фактори впливу.

Постановка завдання. Метою статті $€$ дослідження проблем психологічного благополуччя та психологічного здоров'я соціальних працівників.

Виклад основного матеріалу дослідження. Дослідження останнього десятиріччя визначають нерозривний зв'язок психологіч- 
ного благополуччя та стану психологічного здоров'я людини [7, с. 254]. Психологічне благополуччя $€$ багатогранною концепцією, яка розвивається під впливом емоційної регуляції, особистісних характеристик, життєвого досвіду особистості та самосприйняття. Психологічне благополуччя може збільшуватися з віком, освітою, екстраверсією і свідомістю та зменшується під впливом невротичних станів [7, с. 255].

Поняття «благополуччя» використовується Всесвітньою організацією охорони здоров'я як основний критерій для визначення здоров'я, в якому здоров'я - це не тільки відсутність хвороб або фізичних дефектів, а й стан повного фізичного, розумового і соціального благополуччя [3, с. 173].

Більшість вітчизняних авторів визначає благополуччя, як питання перцепції життя, суб'єктивного ставлення до ситуації і до власних можливостей, відчуття самореалізованості, затребуваності, реалізації свого потенціалу [2, с. 480]. Е.Е. Бочарова наголошує, що різні компоненти благополуччя будуть по-різному поєднуватися і мати різну значимість залежно від індивідуальних, професійних та інших чинників [1, с. 58]

у багатьох країнах благополуччя на роботі стає все більш важливим питанням для більшості професій. У багатьох галузях ведуться жорсткі дискусії про умови праці та відповідальність роботодавців за своїх співробітників. Згідно зі статистикою вигорання працівників стає все більш масовим явищем. Станом на 2017 рік, за даними міжнародного кадрового портала grc.ua, більше половини громадян України (64\%) перебувають у стані емоційного вигорання, тобто у стані виснаження на тлі хронічного стресу, що призводить не тільки до «блокади» всіх сил людини, а й до втрати відчуття радості від життя. У той же час кожен третій українець зазначив, що у нього був такий досвід раніше. Проте зараз їх емоційне здоров'я не є причиною занепокоєння. Тільки 5\% українців повідомили, що не мали такого досвіду, не знають, що таке емоційне вигорання, і чи є які-небудь методи боротьби з цим станом.

Щодо причин емоційного вигорання кожен четвертий українець зазначає, що боїться втратити роботу, оскільки повинен заробляти кошти для себе і своєї сім'ї. Це своєю чергою додає істотного стресу і впливає на результативність роботи і прискорення процесу емоційного вигорання. Адже якщо більша частина ресурсу витрачається на стабілізацію внутрішнього стану, то досить складно зосередитися на виробничих завданнях. Понад $22 \%$ українців стверджують, що основною причиною такого стану для них $€$ невдоволення роботою. Крім того, серед передумов емоційного висна- ження відзначають відсутність професійного розвитку та кар'єрного зростання, а також відчуття безвиході.

Також серед причин наводяться такі, як загальне збільшення робочого навантаження, потік електронної пошти в офісах і страх миттєво втратити роботу. У статті показано, що прогули співробітників в Україні через психічні захворювання за останні п'ятнадцять років збільшилися майже вдвічі.

Особливо ця тенденція простежується в сфері надання допомоги. Надаючи спектр різноманітних послуг різним верствам населення, соціальні працівники зазнають потужного стресу у професійній діяльності, у порівнянні з багатьма представниками інших професій. Високий показник стресу соціальних працівників зумовлений багатоваріантністю професійних завдань та іх значною інтелектуальною й емоційною насиченістю. Через особливі умови соціальні працівники особливо схильні до високого ризику психологічних розладів. Високі очікування з боку громадськості, тиск з боку менеджерів і клієнтів, які часто виявляють небажання і навіть ворожість або насильство, $€$ основними причинами серйозних захворювань серед соціальних працівників [9, с. 98].

Очевидно, що соціальні працівники несуть відповідальність за надання значної кількості сервісів в самих різних умовах. Однак дослідження також показують, що є багато факторів, пов'язаних з роботою в сфері психічного здоров'я, які своєю чергою пов'язані з високим рівнем стресу і вигорання [7, с. 768]. Коли стрес на роботі стає некерованим, він часто приводить до вигорання [4, с. 693].

Рівень вигорання серед фахівців у сфері психічного здоров'я коливається в межах від 21-61\%. В результаті опитування соціальних працівників були виокремлені такі фактори, що сприяють високому стресу: брак ресурсів, необхідність працювати понаднормово, закриття відкритих позицій, великий обсяг роботи і особливо відсутність вдячності з боку роботодавця та з боку суспільства загалом [12, с. 18].

Соціальний працівник служби психічного здоров'я щодня стикається 3 унікальними проблемами. Соціальне благополуччя працівника впливає не тільки на соціального працівника на індивідуальному рівні, але також прямо впливає на результати діяльності агентства і клієнтів, що своєю чергою впливає на систему психічного здоров'я. Рівень підтримки має вирішальне значення для підтримки позитивного благополуччя соціальних працівників [9, с. 100].

Як зазначають H. Kim та M. Stoner, основним ефектом вигорання $є$ плинність кадрів. Соціальні працівники, які перебувають у стані емоційного вигорання, мають більш високий 
рівень прогулів на роботі, відповідно, агентства мають більш високу плинність кадрів. Плинність соціальних працівників негативно впливає на «якість, послідовність і стабільність обслуговування клієнтів» [12, с. 23]. Крім того, плинність кадрів може привести до того, що клієнти будуть відчувати невпевненість щодо наданих соціальних послуг. Плинність кадрів для організації $€$ фінансовим тягарем і джерелом стресу для персоналу, який повинен заповнювати відкриті посади, що своєю чергою може призвести до погіршення якості послуг, що надаються соціальними працівниками [9, с. 105].

Етичний кодекс Національної асоціації соціальних працівників США (2015) починається з твердження: «Основна місія професії соціального працівника - підвищувати добробут людей і допомагати задовольнити основні людські потреби всіх людей» [16, с. 1]. Однак, коли соціальні працівники не отримують достатньої підтримки, їх здатність піклуватися про своїх клієнтів значно знижується; якщо соціальні працівники страждають, то, відповідно, страждають їх клієнти. Отже, важливим $€$ попередження погіршення психологічних станів, надання належного рівня підтримки керівництва та умов, за яких можливо довгострокове якісне обслуговування і підтримка клієнтів [4, с. 692].

Як було зазначено вище, рівень індивідуального благополуччя працівника залежить від досягнення задоволення в багатьох сферах, зокрема таких, як здоров'я, фінанси, дозвілля. З огляду на домінуючу роль, яку професія грає в сучасній ідентичності, здається цілком імовірним, що професійні чинники мають істотний вплив на рівень суб'єктивного благополуччя працівника. [4, с. 698] Враховуючи те, що високий рівень суб' єктивного благополуччя підтримує продуктивність, задоволеність життям, соціально бажану поведінку і хороший фізичний і психічний стан здоров'я, може сприяти продуктивності праці, зменшенню рівня прогулів і рівня плинності кадрів, дуже мало уваги приділяється тому, як професійні групи самі можуть поліпшити суб'єктивне благополуччя працівників-колег.

На нашу думку, необхідне комплексне і систематичне обговорення факторів стресу і діагностика стану соціальних працівників, оскільки це надасть змогу попередити значну кількість проблем та представити потенційні рішення для покращення стану благополуччя соціального працівника.

Наприклад, дослідники G. Morse, M. Salyers, A. Rollins, L. Monroe-DeVita та C. Pfahler стверджують, що протягом декількох місяців працівники служби соціального захисту дітей можуть побачити більше страждань і зазнати більше стресу, ніж більшість інших людей за все життя.
Стверджується, що майже половина всієї соціальної робочої сили США відчуває високий рівень особистих страждань в результаті своєї роботи [16, с. 358]. Це насамперед свідчить про брак адекватної психологічної підтримки соціальних працівників.

Розуміння благополуччя соціального працівника в сфері психічного здоров'я має включати фактори, які можуть вплинути на самопочуття. Дослідники намагаються визначити, які саме фактори стресу переважають в професії «соціальний працівник». Однак знайти ймовірне рішення для поліпшення добробуту соціальних робітників неможливо без урахування конкретних проблем і вимог їх роботи.

Kim H. та Stoner M. визначили основні чинники, що призводять до вигорання соціальних працівників: недостатня кількість персоналу, що призводить до збільшення кількості документів, високого рівня перенавантаження; складні клієнти та відсутність належної психологічної підтримки на робочому місці; надто авторитарне керівництво. Також було виявлено, що серед соціальних працівників найбільш поширеними факторами стресу були нестача ресурсів, необхідність працювати понаднормово через потужну плинність кадрів, великий обсяг роботи, а також відсутність позитивної оцінки керівництва, відчуття жалю за те, що клієнт не може повною мірою оцінити зусилля, вкладені у вирішення його ситуації [12, с. 22].

H. Kim та M. Stoner, провівши дослідження, в якому приймали участь шкільні соціальні працівники, виявили, що є суттєві невідповідності між «Кодексом етики» соціальної роботи та етичними нормами, яких очікує роботодавець, що слугувало серйозним джерелом стресу. Це ж дослідження показало, що зазначені вище невідповідності призводили до перенавантаження і понаднормового обсягу праці [12, с. 24].

Аналіз дослідження за останні десятиріччя щодо плинності кадрів серед соціальних працівників різних категорій, специфічних та глобальних факторів, які впливають на рішення покинути роботу, виявив, що більшість працівників виокремлюють насамперед понаднормову завантаженість, брак персоналу і почуття перевтоми, брак психологічної підтримки. Зазначалося, що фінансові фактори $€$ теж суттєво важливими, але не $є$ визначальними. Більшість опитаних соціальних працівників з високим рівнем емоційного вигорання засвідчили, що не змінили б рішення покинути посаду навіть у разі суттєвого підвищення заробітної плати.

Поряд з чинниками стресу та емоційного вигоряння дуже важливою темою постає виявлення ефектів стресу і вигоряння як на індивідуальному, так і на організаційному 
рівнях. Важливість чіткого розуміння цих ефектів допомагає в точному встановленні проблеми для поліпшення наявних ризиків. Було проведено дослідження для вивчення впливу стресу і вигорання на людину, в якому взяли участь 129 фахівців зі сфери соціальної роботи. Результати показали, що стрес на роботі безпосередньо впливає на особисте здоров'я. Втома від роботи привела до менш здорового способу життя і стійкого почуття незадоволеності роботою, що своєю чергою корелює з відсутністю задоволення в особистому житті [10, с. 13].

Вигорання було пов'язане з погіршенням емоційного і фізичного здоров'я. Наслідками погіршення фізичного та емоційного здоров'я $€$ більш часті випадки депресії, занепокоєння, порушення пам'яті, постійний фізичний біль і надмірне вживання алкоголю [16, с. 343].

У дослідженнях також визначається, що однією з основних причин того, що соціальні працівники залишають місце роботи, є страх за власне здоров'я, як фізичне, так і психологічне [16, с. 343].

Було виявлено, що через вищезазначені чинники стресу, такі як брак ресурсів і перенавантаження, у соціальних працівників суттєво знижується ефективність і якість послуг, що надаються.

Наприклад, було виявлено, що вигорання працівників психіатричної служби було пов'язане зі збільшенням негативних почуттів щодо клієнтів, апатії та байдужості до пацієнта. Крім того, негативні почуття до клієнтів були пов'язані з погіршенням стану клієнтів з психічними захворюваннями [16, с. 350].

Велика частина вивченої літератури також включала пропозиції дослідників щодо вирішення проблем, виявлених у їх дослідженнях.

Наприклад, після кількісного дослідження відмінності факторів стресу між соціальними працівниками, що піклуються про дітей і дорослих, було виявлено, що підтримка з боку керівництва соціальних працівників і керівників агентств була дуже важлива для запобігання вигоранню серед працівників [16, с. 348].

H. Kim та M. Stoner також припустили, що безпосередньо керівництво є потужним механізмом, яке може позитивно вплинути на професійне благополуччя своїх соціальних працівників [12, с. 23].

Дослідження U. Samuel, S. Collins та L. Morris вказують на важливість сприятливого середовища. В першому дослідженні підкреслюється підтримка з боку спільноти, а в останньому з боку самих співробітників.

Також U. Samuel, S. Collins та L. Morris в результаті кількісного дослідження виявили, що соціальні працівники можуть по-різному визначати ефективну підтримку залежно від різних культурних цінностей [5, с. 175].
Натомість J.R. Graham та M.L. Shier досліджували шляхи збільшення продуктивності в соціальній роботі. Благополуччя і продуктивність розглядалися дослідниками як взаємозалежні і взаємопов'язані відносини: «Пов'язане з роботою благополуччя розглядається як центральний компонент продуктивності» [7, с. 768]. У кінцевому підсумку ці автори зазначили, що рефлексивна практика серед соціальних працівників дозволяє їм краще справлятися з проблемами професії, що своєю чергою веде до підвищення продуктивності й ефективності.

Зазначені вище дослідження здебільшого зосереджені на конкретних проблемах у роботі і негативних наслідках, які часто можуть супроводжувати кар'єру в соціальній роботі. Однак $€$ невелика кількість досліджень, які зосереджені на факторах, що сприяють покращенню емоційного стану працівника.

Автори J.R. Graham та M.L. Shier оскаржують спрямованість на дослідження лише негативного впливу, заявляючи, що руйнівні наслідки професії «соціальний працівник» - це тільки половина рівняння. Ці дослідники зазначають, що однобокий аналіз впливу соціальної роботи на благополуччя професіонала, без урахування факторів, що спричиняють позитивний вплив та позитивно позначаються на добробуті, $€$ неповноцінним. Це дозволяє використовувати перспективу сильних сторін, демонструючи важливість зосередження не тільки на дефіциті і тому, що йде не так, але і враховувати можливості соціальних працівників підтримувати свій добробут.

J.R. Graham та M.L. Shier, розвиваючи це дослідження, стверджують, що соціальна робота - це професія, яка часто характеризується стресовими факторами і заохоченням; ці нагороди заслуговують більшої уваги і їх слід використовувати як джерело мотивації. Дослідження, проведене Graham J.R., Shier M.L., виявило, що працівники, які пропрацювали в сфері соціальної роботи понад 10 років, насправді повідомили, що відносини, які в них встановлювалися 3 клієнтами, і задоволення від наданої допомоги були головною нагородою і мотивацією для їх подальшої праці. Це важливе твердження потрібно враховувати, особливо на цей час, коли велика частина соціальної роботи присвячена важким клієнтам як одному з основних факторів стресу в сфері соціальної роботи [10, с. 15].

Це слугує нагадуванням про те, що потрібно враховувати не тільки фактори стресу і проблеми в соціальній роботі, а й позитивний вплив; враховувати не тільки негатив, але і те, що мотивує працівників у рамках професії. Щоб всебічно зрозуміти благополуччя соціального працівника, ми повинні не тільки дивитися, що запобігає благополуччю, а й дивитися, що сприяє йому. 
Попри проблеми, які часто супроводжують кар'єру в соціальній роботі, багато соціальних працівників знайшли здорові способи підтримувати себе і піклуватися про себе. У ряді досліджень було виявлено, що багато працівників самостійно знаходять шляхи подолання професійного стресу, які допомагають підтримувати позитивне відчуття благополуччя як на робочому місці, так і поза ним.

Наприклад, деякі з опитаних повідомили, що використовують практику «Усвідомленість» (Mindfulness). J.R. Graham, M.L. Shier провели дослідження практики усвідомленості Mindfulness серед соціальних працівників, які повідомили про найвищий рівень добробуту. Mindfulness визначається як практика підтримки уваги і усвідомленості, і дослідження показало, що використання практики усвідомленості позитивно вплинуло на благополуччя соціального працівника. Уважність, зокрема, до самоідентифікації і балансу між роботою та особистим життям були особливо важливі та впливові.

Інша практика, яка використовувалась соціальними працівниками, - Духовність (Spirituality). Якщо уважність - це зосередження на теперішньому моменті, то духовна увага, що зосереджена на минулому, як з'ясували J.R. Graham та M.L. Shier, також сприяє підтримці благополуччя соціальних працівників. Це якісне дослідження показало, що соціальні працівники, які мають духовну основу, за допомогою якої вони можуть надати сенс минулому досвіду, особливо негативному, пов'язаному з роботою, з більшою ймовірністю будуть мати вищий рівень психологічного благополуччя [10, с. 16-17].

Крім практик усвідомленості і духовності, $€$ ряд інших досліджень, які виявили фактори, що позитивно впливають на благополуччя соціального працівника.

Дослідження, проведене C. Kang, M. Kim та J. Lee, вивчало навички подолання стресу соціальними працівниками, які почали відчувати негативний вплив роботи на сімейне життя. Дослідження виявило, що соціальні працівники, які витратили час на подальший розвиток особистості, а також почали займатися якимось хобі, краще справлялися зі стресом та вимогами на роботі.

Це свідчить про здатність людини інтуїтивно використовувати позитивні навички подолання труднощів [11, с. 32].

Один с описаних факторів зниження стресу на робочому місці - можливість вчасної відпустки або часу на відновлення сил. C. Kang, M. Kim та J. Lee аналізували вплив відпустки, що триває не менше одного місяця, на рівень психологічного благополуччя соціальних працівників. Автори наголошують, що в сфері надання допомоги позитивні результати у вигляді повноцінного відновлення має відпустка не менше одного місяця. Дослідження показало, що можливість своєчасної повноцінної перерви сприяє одужанню та надає змогу соціальному працівнику повернутися до роботи і бути більш ефективним [11, с. 33-35].

Висновки 3 проведеного дослідження. Більше половини громадян України (64\%) перебувають у стані емоційного вигорання, виснаження та хронічного стресу, що призводить до безсилля, апатії, втрати відчуття радості від життя і хвороб. Особливо страждають від емоційного вигорання працівники соціальної сфери. У статті розглядався стан психологічного благополуччя на прикладі професії соціального працівника. Потрібно зазначити, що існує ряд глобальних проблем, 3 якими стикаються соціальні працівники у робочому процесі, як-от: перенавантаження у зв'язку з великою плинністю кадрів; тиск з боку керівництва, без необхідної працівникам позитивної оцінки їх роботи; труднощі з клієнтами, особливо у соціальних працівників, які працюють з дітьми та сім'ями; неможливість своєчасної та повноцінної відпустки; брак психологічної підтримки працівника. Все це негативно впливає на психологічне благополуччя працівника і $є$ найпоширенішими факторами, що стають причинами звільнення з посади.

\section{ЛITEPATУРA:}

1. Бочарова Е.Е. Взаимосвязь субъективного благополучия и социальной активности личности: кросскультурный аспект. Социальная психология и общество. 2012. № 4. С. 53-63.

2. Карсанова С.А. Стан розробки проблеми психологічного благополуччя у вітчизняній та закордонній психології. Актуальні проблеми практичної психології: збірник наукових праць. Ч. 1. С. 477-483.

3. Кашлюк Ю.І. Основні чинники, які впливають на психологічне благополуччя особистості. Проблеми сучасної психології. 2016. № 34. С. 170-186.

4. Brunsting, N.C., Sreckovic, M.A., \& Lane, K.L. (2014). Special education teacher burnout: A synthesis of research from 1979 to 2013. Education \& Treatment of Children, 37 (4), 681-711.

5. Coffey, M., Samuel, U., Collins, S., \& Morris, L. (2014). A comparative study of social work students in india and the UK: Stress, support and well-being. British Journal of Social Work, 44 (1), 163-180. Retrieved from http://ezproxy.stthomas.edu/login?url=http://search. ebscohost.com.ezproxy.stthomas.edu/ login.aspx?direc $\mathrm{t}=\mathrm{true} \& \mathrm{db}=\mathrm{sih} \& \mathrm{AN}=94184281 \&$ site $=$ ehost-live

6. Craig, S. L., Betancourt, I., \& Muskat, B. (2015). Thinking big, supporting families and enabling coping: The value of social work in patient and family centered health care. Social Work in Health Care, 54 (5), 422-443. doi:10.1080/00981389.2015.1017074

7. Graham, J. R., \& Shier, M. L. (2010). Social work practitioners and subjective well-being: Personal factors that contribute to high levels of subjective wellbeing. International Social Work, 53 (6), 757-772. doi:10.1177/0020872810368394 
8. Graham, J. R., \& Shier, M. L. (2011). Making sense of their world: Aspects of spirituality and subjective wellbeing of practicing social workers. Journal of Religion \& Spirituality in Social Work, 30 (3), 253-271. doi:10.1080 /15426432.2011.587386

9. Graham, J. R., \& Shier, M. L. (2014). Profession and workplace expectations of social workers: Implications for social worker subjective well-being Journal of Social Work Practice, 28 (1), 95-110. doi:10. 1080/02650533.2013.810613

10. Graham, J. R., Shier, M. L., Newberry, A. M., \& Esina, E. (2014). Aligning perspectives of subjective wellbeing: Comparing spouse and colleague perceptions of social worker happiness. Qualitative Report, 19 (23), 1-18. Retrieved from http://ezproxy.stthomas.edu/ login?url=http://search.ebscohost.com.ezproxy.stthoma s.edu/lo gin.aspx?direct=true \&db=sih\&AN=96431072\& site=ehost-live.

11. Kang, C., Kim, M., \& Lee, J. (2011). The effects of a month-long sabbatical program on helping professionals of nonprofit human service organizations in south korea: Burnout, general] health, organizational commitment, and the sense of well-being. Administration in Social Work, 35 (1), 20-45. doi:10.1080/03643107.20 11.533619 .
12. Kim, H., \& Stoner, M. (2008). Burnout and turnover intention among social workers: Effects of role stress, job autonomy and social support. Administration in Social Work, 32 (3), 5-25. doi:10.1080/03643100801922357.

13. Kim, J. (2013). Strengths perspective. Encyclopedia of Social Work. doi: 10.1093/acrefore/9780199975839.013.382.

14. Li, Y., Lan J., \& Ju C. (2015). Self-esteem, gender, and the relationship between extraversion and subjective well-being. Social Behavior \& Personality: An International Journal, 43 (8), 1243-1254. doi:10.2224/ sbp.2015.43.8.1243.

15. Lin Y-C., Yu C., Yi C-C. (2014). The effects of positive affect, person-job fit, and well-being on job performance. Social Behavior and Personality: An International Journal, 42 (9), 1537-1547. doi:10.2224/ sbp.2014.42.9.1537.

16. Morse, G., Salyers, M. P., Rollins, A. L., MonroeDeVita, M., Pfahler, C. (2012). Burnout in mental health services: A review of the problem and its remediation. Administration and Policy in Mental Health, 39 (5), 341-352. http://doi.org/10.1007/s10488-011-0352-1.

17. National Association of Social Workers. (2015). Code of ethics. Retrieved September 26, 2015, from https://www.socialworkers.org/pubs/code/code.asp. 